\title{
Monetary Policy Instruments and Economic Growth in Nigeria: An Empirical Evaluation
}

\author{
Ibrahim Shaibu, Enofe, E. E.
}

To Link this Article: http://dx.doi.org/10.6007/IJARBSS/v11-i5/11304

DOI:10.6007/IJARBSS/v11-i5/11304

Received: 08 March 2021, Revised: 10 April 2021, Accepted: 30 April 2021

Published Online: 24 May 2021

In-Text Citation: (Shaibu \& Enofe, 2021)

To Cite this Article: Shaibu, I., \& Enofe, E. E. (2021). Monetary Policy Instruments and Economic Growth in Nigeria: An Empirical Evaluation. International Journal of Academic Research in Business and Social Sciences, 11(5), 864-880.

\section{Copyright: (c) 2021 The Author(s)}

Published by Human Resource Management Academic Research Society (www.hrmars.com)

This article is published under the Creative Commons Attribution (CC BY 4.0) license. Anyone may reproduce, distribute, translate and create derivative works of this article (for both commercial and non-commercial purposes), subject to full attribution to the original publication and authors. The full terms of this license may be seen at: http://creativecommons.org/licences/by/4.0/legalcode

\section{Vol. 11, No. 5, 2021, Pg. 864 - 880}

Full Terms \& Conditions of access and use can be found at http://hrmars.com/index.php/pages/detail/publication-ethics 


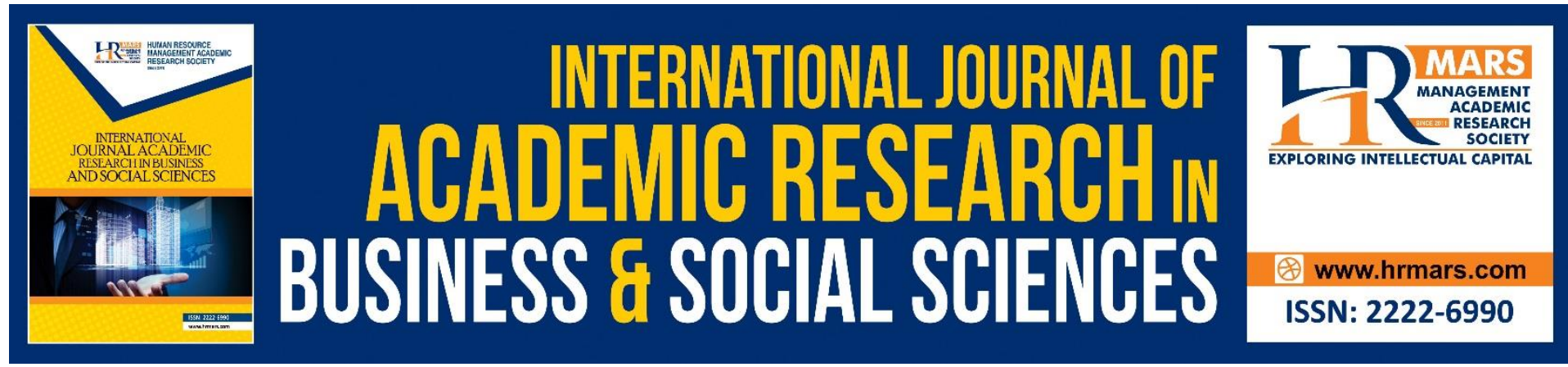

\title{
Monetary Policy Instruments and Economic Growth in Nigeria: An Empirical Evaluation
}

\author{
Ibrahim Shaibu, Ph.D. \\ Associate Professor, Department of Business Administration, University of Benin, Benin City, \\ Nigeria. \\ Email: ibb.shaibu2013@gmail.com \\ Enofe, E. E., Ph.D. \\ Department of Entrepreneurship, University of Benin, Benin City, Nigeria.
}

Email: edwin.enofe@uniben.edu

\begin{abstract}
The aim of this study was to investigate the relationship between monetary policy instruments and economic growth in Nigeria using annual time series data from 1986 to 2018. Within this broad objective, the specific objectives were to ascertain the relationship between: (1) crude oil price and economic growth; (2) exchange rate and economic growth; (3) inflation rate and economic growth in Nigeria; (4) interest rate and economic growth in Nigeria; and (5) broad money supply and economic growth in Nigeria. Economic growth was proxied by real gross domestic product growth rate. The data were sourced from the publications of the Central Bank of Nigeria (CBN), Statista.com, and the World Bank. The estimation technique was the ordinary least squares (OLS)-based auto-regressive distributed-lag (ARDL) method with the aid of EViews software. The estimated model was evaluated using some diagnostic tests (serial correlation test, normality test, and stability test). The empirical results showed that only interest rate had a positive $(0.42)$ and significant $(10 \%)$ impact on economic growth in Nigeria in the short run. In the long run, previous gross domestic product and broad money supply had significant impacts on economic growth in Nigeria. The previous gross domestic product had a negative (-0.72) and significant (10\%) impact while broad money supply had a negative $(-0.000005)$ and significant (5\%) impact on economic growth in Nigeria. In order to effectively use monetary policy instruments in achieving sustainable economic growth, it was recommended that the monetary authority should develop and implement an expansionary monetary policy capable of creating rapid growth of money supply which would lead to a decrease in interest rate which in turn would lead to increase in aggregate investment. These would lead to an increase in economic growth, if properly implemented.
\end{abstract}

Keywords: Auto-Regressive Distributed-Lag (ARDL), Crude Oil Price, Diagnostic Tests, Eviews, Real Gross Domestic Product, Growth Rate. 


\section{Introduction}

Nigeria is an important region in West Africa. It is a federation that has 36 selfgoverning states as well as the Federal Capital Territory (Abuja). With abundant resources, Nigeria is Africa's largest oil exporter with the biggest natural gas reserves on the continent. The economic policies of a country occupy major functions in regulating the degree of its economic operation because they can establish the framework within which economic operations carried out (Barro \& Sala-i-Martin, 1995). The two main economic guidelines for controlling the degree of economic operation in a country are the monetary policy with fiscal policy (Todaro \& Smith, 2009). Monetary policy is concerned with the money supply as well as interest rates which is regularly overseen by the monetary authority, while fiscal policy concerns with public expenditure and debt together with taxation which is always managed by the executive (Dwivedi, 2008).

One of the main policy's purposes of Nigeria is to improve a sustainable economic growth course that could promote the living standard of the populace. In order to attain a sustainable economic growth, Nigeria has adopted diverse economic reform programmes (like SAP, NEEDS and Vision: 20: 2020). In 1986 Nigeria attempted Structural Adjustment Programme (SAP) to guarantee that macroeconomic policies were established more by the directions of market forces that would bring about the diversification of Nigeria's export range of goods and services (Obadan \& Ayodele, 1998). National Economic Empowerment Development Strategy (NEEDS) was employed from 2003 to 2007 in Nigeria in order to achieve an economic reform programme. During the economic framework of NEEDS, Nigerian government used a Medium Term Expenditure Framework (MTEF) which premise was employment creation and comprehensive growth. A longer-term economic development programme was the United Nations (UN)-sponsored National Millennium Goals for Nigeria. During the programme that spanned from years 2000 to 2015 Nigeria promised to attain an ample series of objectives such as international development cooperation, poverty reduction, education, gender equality and health Nigeria's present target is to turn out to be among the top twenty economies in the globe by the year 2020. As the government started to execute the structural reforms stipulated in its Economic Recovery and Growth Plan 2017-2020, growth was estimated to reinforce further in the medium term, getting about 2.8 percent by 2019. There is no doubt that the Nigerian economy has undergone fundamental structural shifts over the last four decades. Nevertheless these structural changes have not brought out result in any noticeable and persistent economic growth as well as development (Agu et al., 2014). This is evidenced in the adverse inflationary trend, undulating foreign exchange rates, unfavourable balance of payments as well as increasing unemployment rates (Agu et al., 2014; lyoha \& Oriakhi, 2002).

The main motive adduced for the disappointment of these strategy measures is the reasonably frail scientific attempts at elucidating the shifts in economic growth in Nigeria. Consequently, policy conclusions are not premised on logical models that trail main economic indices (Adenikinju, Busari, \& Olofin, 2009). Against this background, this research work employed an econometric method to examine the relationships between monetary policy instruments and economic growth in Nigeria. This study tried to do this by using the autoregressive distributed lag (ARDL) method recommended by Pesaran, Shin, and Smith (2001). The ARDL approach can be employed to concurrently estimate short-term and long-term relationships between dependent variable and explanatory variables (Ghatak \& Siddiki, 2001). 


\section{Literature Review}

This segment reviews several related literature on the subject matter of this research work. It considers the concepts of economic growth, fiscal policy, monetary policy, and the empirical reviews on the connection between monetary policy and economic growth in Nigeria.

\section{Economic Growth}

Economic growth is a significant matter in economics and is known as one of the essential conditions to attain improved results on social welfare, which is the major intention of economic policy. According to Hardwick, Khan and Langmead (1994), economic growth is an improvement in the ability of an economy to make goods and services, compared from a period of time to another with the single plan of increasing the economic and financial welfare of the public ( Jhingan, 2008; Ogbulu \& Torbira, 2012). Economic growth is typically measured as the proportion rate of addition in gross domestic product (GDP) (Dolan, Frendreis, \& Tatalovich, 2009). There are not many avenues to create economic growth (Forsythe, 2012). The first is finding of novel or enhanced economic resources. The second means to create economic growth is to produce the labour force (such as more workers produce more economic products). A third avenue to create economic growth is to generate superior technology or other capital products. The fourth way is improved specialization. This implies labourers turn out to be more experienced at their crafts, raising their output through trial and error or simply more practice. An addition in economic growth occasioned by more competent employ of inputs (that is labour productivity, energy or materials and physical capital) is called intensive growth. According to Bjork (1999), GDP growth occasioned only by addition in the quantity of inputs obtainable for exploit (increased population, new territory) is known as extensive growth. An economic growth rate is an appraisal of economic growth from a period to another in proportion terms. In practice, it is a yardstick of the rate of shift that a nation's gross domestic product (GDP) goes through from a year to another. It can be written as follows:

$$
\text { Economic Growth Rate }=\frac{G D P_{2}-G D P_{1}}{G D P_{1}}
$$

The economic growth rate offers insight into the broad track and size of growth for the general economy. Economic growth can be either positive or negative. Positive growth is connected with an addition in the quantity of goods and services generated by an economy over time. Negative growth can be defined as the flinch of the economy and is attached to economic recession and economic depression.

\section{Monetary Policy}

Monetary policy is basically a programme of action undertaken by the monetary authorities, usually the central bank, to regulate and control the supply of money with the public and the stream of credit with an aim to achieve preset macroeconomic goals (Dwivedi, 2008). According to Adegbite and Alabi (2013), monetary policy is an essential instrument that a nation can set up for the maintenance of domestic price and exchange rate stability as a vital circumstance for the attainment of a sustainable economic growth as well as external viability. Monetary policy may be inflationary or deflationary depending upon the economic condition of the country. Twinoburyo and Odhiambo (2018) is of the opinion that contractionary policy is imposed to squeeze down the money supply to control inflation while expansionary policy is set up to motivate economic activities to eradicate unemployment in 
recession. They argue that monetary policy includes a government's formal attempts to control the money in its economy so as to achieve particular economic goals. They assert that there are three fundamental classes of monetary policy decisions can be established (1) the sum of money in circulation; (2) the proportion of interest rates; and (3) the roles of credit markets as well as the banking system. The mixture of these yardsticks is formulated to control the value, supply and cost of money in an economy, in line with the level of economic activities. Excess supply of money will necessitate excess demand for goods and services; prices will increase and balance of payments will decline. The bottleneck of monetary policy management rests completely on monetary authorities, which have over the years been committed to its effective control.

\section{Empirical Review}

Extensive study has been carried out in an effort to ascertain the effect of monetary policy on economic growth. Ogunmuyiwa and Ekone (2010) examined the relationship between money supply and economic growth in Nigeria between 1980 and 2006. The OLS and ECM were used. The study's finding showed a positive effect of money supply on economic growth both in short run and long run. Adegbite and Alabi (2013) investigated 'the impact of monetary policy on economic growth in Nigeria from 1970 to 2010' using multiple regression method to assess the model. The study' s finding revealed that money supply, inflation, exchange rate, and interest rate have significant effects on the economic growth. Fasanya, Onakoya, and Agboluaje (2013) investigated 'the impact of monetary policy on economic growth in Nigeria using the error correction model (ECM) on time-series data covering 1975 to 2010'. The study's findings showed that a long-run relationship exists among the variables and that inflation rate, exchange rate, and external reserves are significant monetary policy instruments that drive growth in Nigeria in accordance with theoretical expectations. Money supply was discovered to be insignificant. Omolade, Ashamu, and Morakinyo (2013) worked on 'the impact of monetary policy on Nigeria's economic growth between 1970 and 2005.' Employing the cointegration as well as error correction model, the finding indicated a long run association between growth and monetary policy variables. The long run association also revealed that only the exchange rate had significant effect on the growth of Nigeria.

Imoughele and Ismaila (2014) investigated 'the extent to which monetary policy affects the manufacturing sector between 1986 and 2012'. The study discovered that manufacturing sector's output was increased by exchange rate, inflation rate, and external reserve. However, the supply of broad money (M2) together with interest rate failed statistical significance on the output of the industry. Nwoko, Ihemeje and Anumadu (2016) investigated 'the extent to which the Central Bank of Nigeria monetary policies could effectively be used to promote economic growth, covering the period of 1990-2011'. The effect of money supply and interest rate were assesed on gross domestic product employing the multiple regression models as the main statistical tool of analysis. The study's findings revealed that while money supply was not significant, interest rate was negative and statistically significant in explaining gross domestic product (GDP) dynamics in Nigeria.

Ogbonna and Uma (2017) investigated 'the influence of monetary policy tools on economic growth of Nigeria from 1980 to 2016' employing annual data series. The study used Johansen cointegration test and vector error correction model (VECM). The study's findings indicated that money supply, exchange rate, interest rate and inflation rate had significant influences on real gross domestic product. Broad money supply had inverse relationship with real gross domestic product in the reviewed period. Oluseyi, Olasehinde, and Eweke (2017) studied 'the 
long and short-run affiliations between broad money supply and real aggregate output (GDP) between 1981 and 2015 in Nigeria' employing the autoregressive distributed-lag (ARDL) technique. The findings from ARDL analysis indicated that money supply influenced significantly on real GDP in the long run only. Ezeaku, Ibe, Ugwuanyi, Modebe, and Agbaeze (2018) assessed 'the effects of monetary policy transmission channels on industrial growth in Nigeria within the period 1981-2014.' The study employed Johansen cointegration and the error correction model (ECM). The findings showed that interest rate and exchange rate channels had negative impacts on real output growth, in the long run as well as in the short run.

John and Udoye (2018) evaluated 'the effect of monetary policy on the Nigerian economy using data obtained from Central Bank of Nigeria from 1995 to 2016'. Interest rate, exchange rate, inflation rate and ratio of broad money supply (BMS) to gross domestic product (GDP) were used as the independent variables, while GDP growth rate was used as the dependent variable. The ordinary least squares (OLS) regression outcomes revealed that inflation had a significant positive influence on economic growth, whereas interest rate, exchange rate, and broad money supply had a negative but not significant influence on economic growth in Nigeria. Tule, Ogundele, and Apinran (2018) examined the effect of monetary policy instruments in Nigeria using data from year 2000 to 2016'. The study employed the Johansen multivariate cointegration approach and vector error correction mechanism (VECM). The cointegration test ascertained presence of long-term association between monetary policy instruments and economic growth. The results showed that inflation, real exchange rate (RER), broad money supply (M2), and interest rate (INT) had significant relationships with monetary policy instruments that propelled economic growth in Nigeria during the period under review.

Ufoeze, Odimgbe, Ezeabalisi, and Alajekwu (2018) examined 'the effect of monetary policy on economic growth in Nigeria from 1986 to 2016'. The gross domestic product (GDP) was employed as the dependent variable while the independent monetary policy variables were the monetary policy rate, money supply, exchange rate, lending rate and investment. They used the ordinary least squares technique as well as carried out the unit root and cointegration tests. The study's findings revealed that monetary policy rate, interest rate, and investment had insignificant positive influence on economic growth in Nigeria. Money supply however had significant positive influence on growth in Nigeria. Exchange rate had significant negative influence on GDP in Nigeria.

\section{Methodology}

\section{Data, Sources, and Description}

This study used annual data from 1986 to 2018. The variables used were the real gross domestic product growth rate (RGDPGRT), crude oil price (CRUDEOILP), exchange rate (EXCRT), inflation rate (INFN), interest rate (INTRT), and broad money supply (M2). The data were sourced from the publications of the Central Bank of Nigeria (CBN), and the World Bank. Economic growth rate (EGR) is a yardstick of economic growth from a particular period to another in percentage terms. CRUDEOILP is a product of crude oil production and the prevailing international CRUDEOILP. EXCRT is the price of one nation's currency in terms of another nation's currency. It is computed as an annual average based on monthly averages (local currency units relative to the U.S. dollar). INFN as measured by the consumer price index shows the annual percentage change in the cost to the average consumer of acquiring a basket of goods and services that may be fixed or variable at particular intervals, such as 
annually. Interest rate (lending) is the value charged and expressed as a proportion of principal by providers of loan to a borrower typically noted on annual basis. Broad money supply (M2) is described as the amount of currency in the hands of the public plus all of the public's deposits in commercial banks.

\section{Theoretical Framework and Model Specification}

The proof that is inconsistent with theoretical anticipations from diverse examinations is what economists generally call "puzzles". The three mainly universal puzzles acknowledged in the extant literature are the liquidity puzzle, the price puzzle, and the exchange rate puzzle. The liquidity puzzle is a result that an addition in monetary aggregates is associated with an addition (rather than a decrease) in interest rates. While the price puzzle is the discovery that a contractionary monetary policy through positive innovations in the interest rate seems to bring about an addition (rather than a decrease) in prices. The exchange rate puzzle is a detection that an addition in interest rate is accomplished by depreciation (rather than appreciation) of the local legal tender. In existing studies, researchers have devised expedient means of eliminating these puzzles. Most of the studies now adopt the framework developed by Lucas (1972) who suggested the integration of rational anticipations in the study of the impacts of monetary policy.

The examination of the relationship between monetary policy instruments and economic growth in Nigeria is premised on the neoclassical framework which promotes a steady growth state. The starting point of conventional economic growth theorization is the neoclassical model set up by Robert Solow (1956) and Trevor Swan (1956) which concerned a sequence of equations indicating the relationship between labour-time, capital goods, output and investment. A key issue with growth modelling is the establishment of the variables to incorporate as potential growth determinants (Petrakos, Arvanitidis \& Pavleas, 2007; Ristanović, 2010). This matter results because of the open-endedness of growth theories whereby the validity of one causal theory does not involve the falsity of another. To deal with the matter of open-endedness, some researchers such as Levine and Renelt (1992) have proposed means to handle the robustness of variables in growth regressions by identifying a stream of possible variables for enclosure. Enclosure of a variable in the final choice requires that its related coefficient proves to be robust. A coefficient is robust if the sign of its OLS remains consistent across a set of regressions representing diverse potential mixtures of other variables. The size of contemporary empirical studies on growth has centred on growth regressions of the kind formulated by Barro (1991). A basic form for growth regression is:

$$
g_{i}=X_{i} \gamma+Z_{i} \pi+\varepsilon_{i}
$$

where $g_{i}$ is growth in economy $i$ over a given period of time. $X_{i}$ represents variables which existence is recommended by Solow's (1956) growth model: a consistent, original income and a set of country-specific savings and population growth controls. The Solow's model is always considered as a baseline from which to build up more elaborate growth models, therefore these variables tend to be regular across studies. $Z_{i}$, in contrast, comprises of variables selected to capture additional growth determinants that a researcher holds that are imperative and so commonly vary across analysis.

Starting from the main macroeconomic relation, with the target to deal with the influence that monetary policy tools (exchange rate, inflation rate, interest rate, broad money supply, and crude oil price) have on economic growth (proxied by gross domestic product growth rate), Equation (2) is improved by the effect of exchange rate, inflation rate, interest rate, broad money supply, and crude oil price. 


$$
R G D P G R T=f(C R U D E O I L P, E X C R T, I N F N, I N T R T, M 2)
$$

Where:

RGDPGRT refers to real gross domestic product growth rate; CRUDEOILP is crude oil price; EXCRT is exchange rate; INFN is inflation rate; INTRT is interest rate; and M2 is broad money supply

The autoregressive representation of the model can be stated as:

$$
\begin{aligned}
R_{\text {RDPGRT }}= & \alpha_{0}+\alpha_{1} R G D P G R T_{t-1}+\alpha_{2} \text { CRUDEOILP }_{t}+\alpha_{3} \text { EXCRT }_{t}+\alpha_{4} I_{N F N_{t}}+\alpha_{5} I N T R T_{t} \\
& +\alpha_{6} M 2_{t}+\varepsilon_{t}
\end{aligned}
$$

Therefore, apriori expectations of the coefficients are:

An increase in the previous value of economic growth will lead to an increase in the $\alpha_{1}>0$ :

$$
\text { value of current economic growth. }
$$

An increase in crude oil price will lead to an increase in economic growth. $\alpha_{2}>0$ :

An increase in exchange rate will lead to a decrease in economic growth. $\alpha_{3}<0$ :

An increase in inflation rate will lead to a decrease in economic growth. $\alpha_{4}<0$ :

An increase in interest rate will lead to a decrease in economic growth. $\alpha_{5}<0$ :

An increase in broad money supply will lead to an increase in economic growth. $\alpha_{6}>0$ :

In order to develop a strong, robust, and reliable model that captures the short-term and longterm relationship between monetary policy variables and economic growth, the research adopts the econometric technique of the autoregressive distributed lag (ARDL) model. The model was developed by Pesaran et al (2001). The autoregressive distributed lag (ARDL) approach is a regression technique for determining long-run and short-run relationships among variables under study simultaneously. The ARDL approach is extensively employed in regression primarily because it can be applied irrespective of the order of integration of the series (Banerjee, Dolado, \& Mestre, 1998; Ghatak \& Siddiki, 2001) and can therefore be estimated directly as a multivariable single equation.

Following Pesaran et al (2001), the autoregressive distributed lag (ARDL) representation of the model (Equation 4) is specified as follows: 


$$
\begin{aligned}
\Delta R G D P G R T_{t}= & \alpha_{0}+\sum_{i=1}^{n} \alpha_{1 i} \Delta R G D P G R T_{t-i}+\sum_{i=0}^{n} \alpha_{2 i} \Delta \text { CRUDEOILP }{ }_{t-i}+\sum_{i=0}^{n} \alpha_{3 i} \Delta E X C R T_{t-i}+\sum_{i=0}^{n} \alpha_{4 i} \Delta I N F N_{t-i} \\
& +\sum_{i=0}^{n} \alpha_{5 i} \Delta I N T R T_{t-i}+\sum_{i=0}^{n} \alpha_{6 i} \Delta M 2_{t-i}+\beta_{1} R G D P G R T_{t-1}+\beta_{2} \text { CRUDEOILP }_{t-1}+\beta_{3} \text { EXCRT }_{t-1} \\
& +\beta_{4} \text { INFN }_{t-1}+\beta_{5} \text { INTRT }_{t-1}+\beta_{6} M 2_{t-1}+\varepsilon_{t}
\end{aligned}
$$

where :

RGDPGRT $_{t}=$ Current value of real gross domestic product growth rate,

RGDPGRT $_{t-i}=$ Past value of real gross domestic product growth rate,

CRUDEOILP $_{t}=$ Current value of crude oil price,

CRUDEOILP $_{t-i}=$ Past value of crude oil price,

EXCRT $_{\mathrm{t}}=$ Current value of exchange rate,

$\mathrm{EXCRT}_{t-i}=$ Past value of exchange rate,

$\mathrm{INFN}_{t}=$ Current value of inflation rate,

$\mathrm{INFN}_{t-i}=$ Past value of inflation rate,

INTRT $_{t}=$ Current value of interest rate,

INTRT $_{t-i}=$ Past value of interest rate,

M2 ${ }_{t}=$ Current value of broad money supply,

$\mathrm{M} 2_{t-i} \quad=$ Past value of broad money supply,

$t=$ time period, $\sum=$ summation, $\Delta$ denotes the first difference operator,

$\alpha_{0}$ is the constant component, and $\varepsilon_{t}$ is the residual or stochastic term.

The left-hand side of the model (Equation 5 ) is the economic growth represented by the real gross domestic product growth rate (RGDPGRT). The terms with the summation signs $\alpha_{1}$ to $\alpha_{6}$ on the right-hand side of the model (Equation 5) represent the short-run relationship of the model. The first to the sixth term with beta signs $\beta_{1}, \beta_{2}, \beta_{3}, \beta_{4}, \beta_{5}$, and $\beta_{6}$ on the righthand side of the model (Equation 5 ) correspond to the long-run relationship of the model.

\section{Empirical Results}

The analyses were conducted in two stages. The first stage was some pre-estimation analyses to establish the stationarity of the variables choosen for the model, co-integration test to determine if there is a long-run stable relationship among the variables, and correlation test to investigat the strength and direction of the linear relationship among the variables. The second stage was the estimation of the ARDL model and post-estimation analyses (diagnostics testing of the model).

\section{Unit Root Tests for the Variables}

The use of ARDL models does not impose pre-testing of variables for unit root problems. However, unit root tests are conducted in this study to find out if there are combinations in the order of integration of our variables. The order of integration of the time series was examined by the Augmented Dickey-Fuller (1979) test. The Augmented Dickey-Fuller (ADF) unit root test results for the time series variables are presented in Table 1 below. 
Table 1: The Augmented Dickey-Fuller (ADF) Unit Root Test Results

\begin{tabular}{|c|c|c|c|c|c|}
\hline Variable & $\begin{array}{lr}\text { ADF } & \text { Test } \\
\text { Statistic } & \text { at } \\
\text { Level } & \end{array}$ & $\begin{array}{|lr|}\text { ADF } & \text { Test } \\
\text { Statistic } & \text { at } \\
\text { 1st } & \\
\text { Difference } & \\
\end{array}$ & $\begin{array}{l}95 \% \\
\text { Critical } \\
\text { ADF } \\
\text { Value }\end{array}$ & $\begin{array}{l}\text { Order of } \\
\text { Integration }\end{array}$ & Remark \\
\hline CRUDEOILP & -1.303877 & $-4.760430 *$ & -2.960411 & $I(1)$ & Stationary \\
\hline EXCRT & -1.305899 & $-3.981215^{*}$ & -2.960411 & $I(1)$ & Stationary \\
\hline INFN & -2.688275 & $-6.860664^{*}$ & -2.963972 & $I(I)$ & Stationary \\
\hline INTRT & $-3.340240 * *$ & & -2.957110 & $I(0)$ & Stationary \\
\hline M2 & -0.161642 & $-15.26070^{*}$ & -2.963972 & $I(2)$ & Stationary \\
\hline RGDPGRT & $-2.993619 * *$ & & -2.957110 & $I(0)$ & Stationary \\
\hline
\end{tabular}

Source: Researchers' calculation by EViews (2019).

The ADF tests in Table 1 show that interest rate (INTRT) and real gross domestic product growth rate (RGDPGRT) were stationary at level, crude oil price (CRUDEOILP), exchange rate (EXCRT), and inflation (INFN) were stationary at first difference, while broad money supply (M2) became stationary at second difference. Thus co-integration test has to be performed.

\section{Co-Integration Test}

The Engel and Granger (1987) co-integration test is used for single equation models. The cointegration test result for the research model is presented in Table 2 below.

Table 2: Engel and Granger Residual Based Co-Integration Test Result

\begin{tabular}{|l|l|l|l|l|}
\hline SERIES & ADF & 5\% CRITICAL VALUE & ORDER OF INTEGRATION & REMARK \\
\hline RESIDUAL & -5.39 & -2.964 & I (0) & Co-integrated \\
\hline
\end{tabular}

Source: Researchers' calculation by EViews (2019).

The results in Table 2 show that there is co-integration among real gross domestic product growth rate (RGDPGRT), crude oil price (CRUDEOILP), exchange rate (EXCRT), inflation rate (INFNRT), interest rate (INTRT), and broad money supply (M2) since the ADF test value for the residual is greater (absolute values) than the critical value. Thus, the time series are cointegrated, implying that a long-run stable relationship exists among the variables used in this study. This means that any short-run deviation in their relationships would return to equilibrium in the long-run.

\section{Correlation Matrix}

A correlation matrix is a table showing correlation coefficients between variables. Correlation measures both the strength and direction of the linear relationship between two variables. When there is a positive correlation between two variables, as the value of one variable increases, the value of the other variable also increases. The variables move together. In examining the relationship among the variables, we employed the Pearson correlation coefficient (correlation matrix) and the results are presented in Table 3. 
Table 3: Pearson Correlation Matrix

\begin{tabular}{|l|l|l|l|l|l|l|}
\hline Variable & RGDPGRT & CRUDEOILP & EXCRT & INFN & INTRT & M2 \\
\hline RGDPGRT & 1.000000 & 0.233726 & 0.049186 & -0.226569 & 0.183163 & 0.151524 \\
\hline CRUDEOILP & & & & & & \\
& 0.233726 & 1.000000 & 0.325557 & -0.414616 & -0.399038 & 0.291003 \\
\hline EXCRT & 0.049186 & 0.325557 & 1.000000 & -0.426886 & -0.426886 & 0.389356 \\
\hline INFN & -0.226569 & -0.414616 & -0.426886 & 1.000000 & 0.420232 & 0.332552 \\
\hline & & & & & & - \\
INTRT & 0.183163 & -0.399038 & -0.249898 & 0.420232 & 1.000000 & 0.364963 \\
\hline M2 & -0.151524 & 0.291003 & 0.389356 & -0.332552 & -0.364963 & 1.000000 \\
\hline
\end{tabular}

The correlation coefficients show that crude oil price $(0.233726)$, exchange rate $(0.029186)$, and interest rate $(0.183163)$ have a weak but positive relationship with economic growth (real gross domestic product growth rate). This means that increase in crude oil price, exchange rate, and interest rate is associated with increase in economic growth. On the other hand, inflation rate and broad money supply have weak and negative relationship with economic growth (real gross domestic product growth rate). This means that increase in inflation rate and broad money supply is associated with decrease in economic growth (real gross domestic product growth rate) in Nigeria. The correlation among the explanatory variables shows that there is the absence of strong relationship among them. This means that there is no evidence of the presence of multicolinearity in the specified model (Equation 5).

\section{Model Estimation and Diagnostic Tests}

The autoregressive distributed-lag ( $A R D L$ ) is a technique that allows us to simultaneously estimate the short-run and long-run coefficients of our model. The estimated auto-regressive distributed lag (ARDL) model is presented in Table 4. 


\begin{tabular}{|c|c|c|c|}
\hline \multirow[t]{2}{*}{ Dependent Variable: RGDPGRT } & & & \\
\hline & Coefficient & (t-statistic) & Probability \\
\hline Constant & 7.05 & $(1.17)$ & 0.26 \\
\hline \multicolumn{4}{|l|}{ Independent Variables } \\
\hline \multicolumn{4}{|l|}{ Short-Run Results } \\
\hline $\begin{array}{l}\text { Previous real gross domestic product growth } \\
\text { rate }\end{array}$ & -0.09 & -0.37 & 0.71 \\
\hline Current crude oil price & -0.01 & -0.22 & 0.83 \\
\hline Previous current crude oil price & -0.05 & -0.93 & 0.37 \\
\hline Current value of exchange rate & -0.08 & -1.55 & 0.15 \\
\hline Previous value of exchange rate & -0.02 & -0.34 & 0.74 \\
\hline Current value of inflation rate & -0.07 & -0.99 & 0.34 \\
\hline Previous value of inflation rate & 0.05 & 0.66 & 0.52 \\
\hline Current value of interest rate & 0.42 & $2.04 * * *$ & 0.06 \\
\hline Previous value of interest rate & 0.14 & 0.49 & 0.63 \\
\hline Current value of broad money supply & -0.0000008 & -0.68 & 0.51 \\
\hline Previous value of broad money supply & -0.000001 & 0.94 & 0.36 \\
\hline \multicolumn{4}{|l|}{ Long-Run Results } \\
\hline $\begin{array}{l}\text { Previous real gross domestic product growth } \\
\text { rate }\end{array}$ & -0.72 & $-2.58 * *$ & 0.02 \\
\hline Crude oil price & 0.002 & 0.04 & 0.97 \\
\hline Exchange rate & 0.05 & 1.35 & 0.20 \\
\hline Inflation rate & -0.03 & -0.30 & 0.77 \\
\hline Interest rate & -0.18 & -0.65 & 0.53 \\
\hline Money supply & -0.0000006 & $-2.47^{* *}$ & 0.02 \\
\hline R-squared & 0.74 & & \\
\hline Adjusted R-squared & 0.395 & & \\
\hline F-statistic & 21.5 & & \\
\hline Prob (F-statistic) & 0.08 & & \\
\hline Durbin-Watson statistic & 1.96 & & \\
\hline
\end{tabular}

After estimating the empirical ARDL model, a variety of diagnostic tests were carried out to enhance the credibility of the model. The serial correlation (Breusch-Godfrey serial correlation LM) test, the normality (Jarque-Bera), the forecasting performance (RMSE and MAE) test, and the stability (cumulative sum of squares, CUSUM-SQ) test were conducted. The results of the respective tests are presented in Table 7 and Figure 1. 
Table 5: ARDL Model Diagnostic Tests

\begin{tabular}{|l|l|l|}
\hline TEST & $\begin{array}{l}\text { F-STATISTIC } \\
\text { (Prob) }\end{array}$ & VALUE \\
\hline $\begin{array}{l}\text { Serial Correlation: Breusch-Godfrey serial correlation } \\
\text { LM test }\end{array}$ & $0.499(0.62)$ & \\
\hline Normality: Jarque-Bera test. & $1.28(0.52)$ & \\
\hline Root Mean Square Error (RMSE) & & 1.90 \\
\hline Mean Absolute Error (MAE) & & 1.40 \\
\hline
\end{tabular}

Source: Researchers' calculation by EViews (2019).

The diagnostics indicate that the residuals were serially uncorrelated and normally distributed based on Breusch-Godfrey serial correlation LM test and Jarque-Bera test respectively. When forecast values are closer to each other, a small forecast error will be obtained. Thus, smaller RMSE and MAE are preferred. The results show that the model is relevant for forecasting economic growth in Nigeria.

The stability properties of the ARDL model were examined. We applied the CUSUM-of-squares (CUSUM-SQ) test, which Brown, Durbin, and Evans (1975) developed. According to BahmaniOskooee and Wing NG (2002), if the plot of these statistics remains within the critical bound of the $5 \%$ significance level, the null hypothesis (that is, all coefficients in the model are stable) cannot be rejected. A graphical presentation of this test for our ARDL model is provided in Figure 1 below.

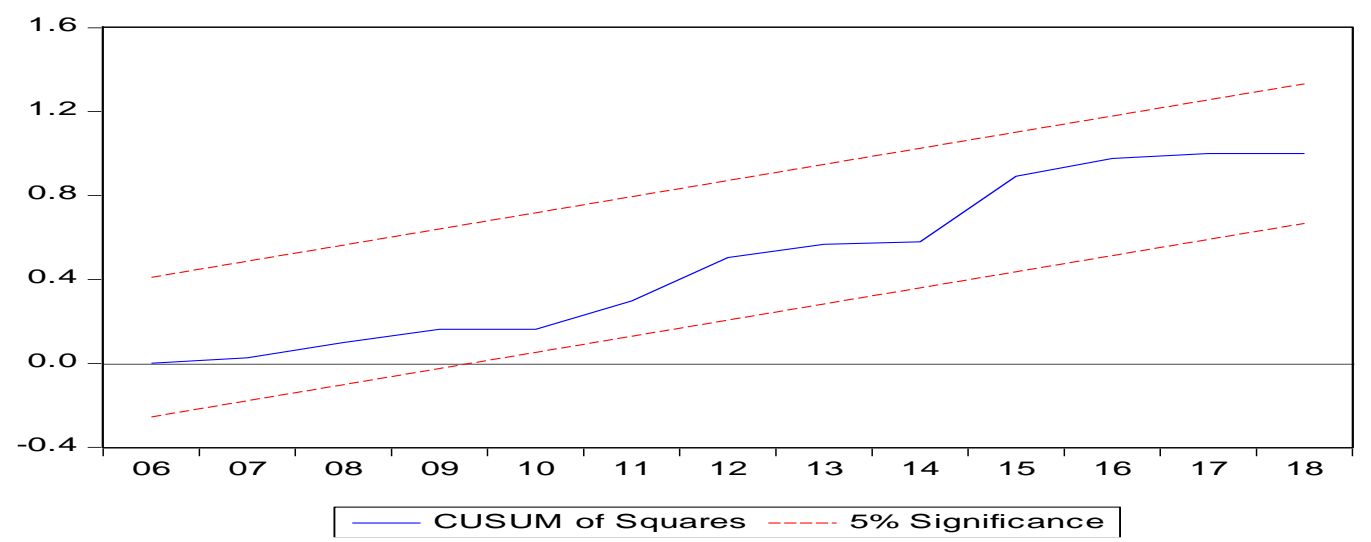

Figure 1: Cumulative sum of squares (CUSUM-SQ) of recursive residuals plot. Source: Researchers' calculation by EViews (2019).

Since the plot of the cumulative sum of squares (CUSOM-SQ) statistic for economic growth does not cross the critical value lines as Figure 1 indicates, it is therefore safe to conclude that ARDL economic growth model is stable and economic growth can be used as a target variable.

\section{Model Interpretation}

The diagnostic results of the model show that the ARDL model performs very well. In other words, this ARDL model can be applied in explaining the impact of monetary policy tools on economic growth in Nigeria. We can therefore interpret the model. The empirical model extracted from the regression results (Table 4) is stated in Equation 6 below. 


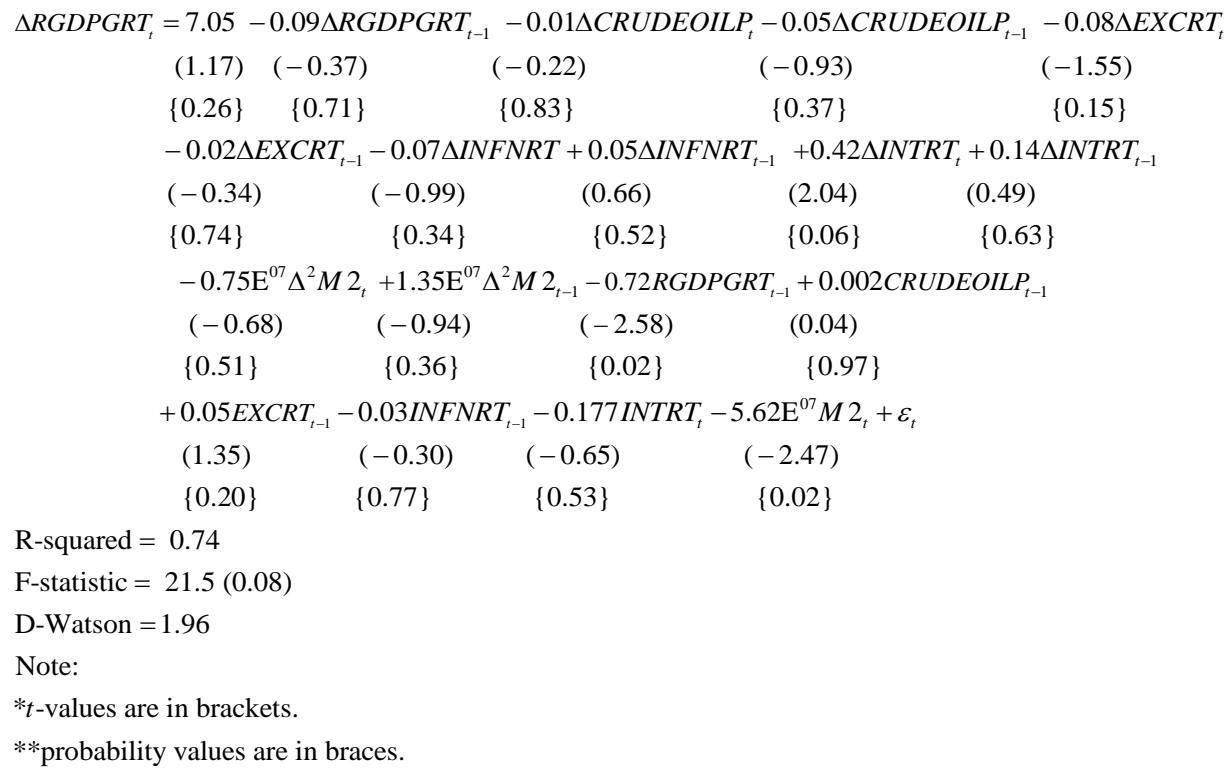
changes in economic growth of Nigeria is jointly explained and accounted for by the monetary policy variables in the estimated ARDL model. The F-test which is used to determine the overall statistical significance of a regression model shows that the overall regression is statistically significant at $10 \%$ level. This implies that the ARDL model has a satisfactory goodness-of-fit.

In terms of the signs, significance, and magnitudes of the impacts of monetary policy instruments on economic growth, it was observed from the model that in the short run, exchange rate and inflation rate had signs that are consistent with theoretical expectation while the previous value of economic growth, crude oil price, and interest rate had signs contrary to their theoretical expectation. In the long run, inflation rate and interest rate had signs that are consistent with theoretical expectation while previous value of economic growth, exchange rate, and broad money supply had signs contrary to their theoretical expectations.

In the short run as shown above, only interest rate has significant impact on economic growth in Nigeria. Interest rate has a positive and significant (10\%) impact on economic growth during the study period. This finding is consistent with the findings of Adegbite and Alabi (2013), Ogbonna and Uma (2017), and Tule, Ogundele, and Apinran (2018). A percent increase in the current rate of interest will increase economic growth in Nigeria by $0.42 \%$. In the long run, the previous value of economic growth and broad money supply are the significant variables influencing the economic growth dynamics in Nigeria during the study period. The previous value of economic has a negative and significant (5\%) impact on economic growth in Nigeria. This is not consistent with the finding of Fasanya, Onakoya, and Agboluaje (2013). A percent increase in the previous growth rate of real gross domestic product will reduce economic growth in Nigeria by $0.72 \%$. Broad money supply (M2) has a negative and significant $(5 \%)$ impact on economic growth in Nigeria during the study period. This finding is consistent with the findings of Fasanya, Onakoya, and Agboluaje 2013) and Ogbonna and Uma (2017). A unit increase in the broad money supply will reduce economic growth in Nigeria by $0.000005 \%$.

\section{Conclusion and Policy Recommendations}

Monetary policy implementation in a developing country like Nigeria faces some challenges that are not present in developed countries, such as fiscal dominance and the threat of 
currency substitution. This study investigated the relationship between monetary policy instruments (crude oil price, exchange rate, inflation rate, interest rate, and broad money supply and economic growth (real gross domestic product growth rate) in Nigeria using annual time series data from 1986 to 2018. The data were sourced from the publications of the Central Bank of Nigeria (CBN), Statista.com, and World Bank. By considering recent empirical studies in the context of monetary policy and economic growth, an autoregressive distributed-lag model which emphasized the effect of monetary policy instruments on economic growth was identified, specified, and estimated. Diagnostic tests for serial correlation (Breusch-Godfrey serial correlation LM test), normality (Jarque-Bera test), stability (CUSUM and CUSUM-of-squares tests), and forecasting performance test were used to evaluate the estimated model.

This study has established that monetary policy in Nigeria depended on major policy instruments such as exchange rate, interest rate, and monetary base. The study concludes from the findings that only interest rate variable has (positive) significant impact on economic growth in Nigeria in the short-run. In the long run, the previous gross domestic product (negative) and broad money supply (negative) are the variables that have significant impacts on economic growth in Nigeria. On the basis of the findings, we make the following recommendations:

It was found that the current rate of interest rate had a positive $(0.42)$ and significant (10\%) impact on economic growth in Nigeria. This finding is not consistent with the theoretical expectation that suggests a negative relationship. The anomaly has to be corrected. It is therefore recommended that government should ensure that changes in short-term market interest rate are passed through to retail interest rates for loans and deposits, which would influence the overall level of economic activity and prices.

It was found that previous value of economic growth had a negative $(-0.72)$ and significant (5\%) impact on economic growth in Nigeria in the long run. The inference that can be drawn from this is that economic growth function follows the rational expectations theory. That is, expectations that are formed about past levels of economic growth affect the current economic growth. This finding is not consistent with the theoretical expectation that suggests a positive relationship. We therefore recommend that government should ensure transparency in monetary policies implementation.

It was found that broad money supply public had a negative $(-0.000005)$ and significant $(5 \%)$ impact on economic growth in Nigeria. This finding is not consistent with the theoretical expectation that suggests a positive relationship. In monetary policy transmitting mechanism, the supply of money plays a pivotal role especially in developing countries like Nigeria where a strong monetary base is often advised by the stakeholders so as to allow for smooth transmitting adjustment within the system. We therefore recommend that the monetary authority should engage in massive expansionary monetary policy money which would lead to a decrease in interest rate which in turn would result to increased investment. All these actions will lead to an increase in aggregate demand (economic growth) if they are properly implemented.

\section{References}

Adegbite, T. A., \& Alabi, W. O. (2013). Monetary policy and economic growth: The Nigerian experience (1970-2010). Prime Journal of Business Administration and Management, $3(1), 822-833$. 
Adenikinju, A., Busari, D., \& Olofin, S. (2009). Applied econometrics and macroeconometric modelling in Nigeria. Ibadan: Ibadan University Press.

Agu, S. U., Idike, A. N., Okwor, I. M., \& Ugwunta, D. (2014). Fiscal policy and economic growth in Nigeria: Emphasis on various components of public expenditure. Singaporean Journal of Business Economics and Management Studies, 2 (12), 20-14.

Bahmani-Oskooee, M., \& Wing NG, R. C. (2002). Long-run demand for money in Hong Kong: An application of the ARDL model. International Journal of Business and Economics, 1 (2), 147-155

Banerjee, A., Dolado, J., \& Mestre., R. (1998). Error correction mechanism tests for cointegration in a single equation framework. Journal of Time Series Analysis, 19 (3), 267-283.

Barro, R., \& Sala-i-Martin, X. (1995). Economic growth. New York: McGraw-Hill.

Barro, R. J. (1991). Economic growth in a cross section of countries. Quarterly Journal of Economics, 106 (2), 407-443.

Bjork, G. (1999). The way it worked and why it won't: Structural change and the showdown of U.S. economic growth. Westport, CT, London: Praeger. https/wikepadia/w/index. Retrieved Sep. 2016

Brown, R. L., Durbin, J., \& Evans, J. M. (1975). Techniques for testing constancy of regression relationship over time. Journal of the Royal Statistical Society B37, 149-192.

Dickey, D. A., \& Fuller, W. A. (1979). Distribution of the estimators for autoregressive time series with a unit root. Journal of the American Statistical Association, 74, 427-431.

Dolan, C. J., Frendreis, J., \& Tatalovich, R. (2009). A presidential economic scorecard: Performance and perception. PS: Political Science and Politics, 42, 689-694.

Dwivedi, D. N. (2008). Managerial economics (6th ed.). New Delhi: VIKAS Publishing House.

Engle, R. F., \& Granger, C. W. J. (1987). Co-integration and error-correction: representation, estimating and testing. Econometrica, 55, 251-276.

Ezeaku, H. C., Ibe, I. G., Ugwuanyi, U. B., Modebe, N., \& Agbaeze, E. K. (2018). Monetary policy transmission and industrial sector growth: Empirical evidence from Nigeria. Sage Open, 8 (2): 2158244018769369 . Available at: https://doi.org/10.1177/2158244018769369.

Fasanya, I. O., Onakoya, A. B. O., \& Agboluaje, M. A. (2013). Does monetary policy influence economic growth in Nigeria? Asian Economic and Financial Review, 3 (5), 635-646. Retrieved from www.aessweb.com/download.php?id=1883.

Forsythe, A. (2012). Fiscal policy. Economics.fundamentalfinance.com. Retrieved 9/4/16, 11:41am.

Ghatak, S., \& Siddiki, J. (2001). The use of ARDL approach in estimating virtual exchange rates in India. Journal of Applied Statistics, 28(5), 273-583.

Hardwick, P., Khan, B., \& Langmead, J. (1994). An introduction to modern economics. England: Longman Group Ltd.

Imoughele, L. E., \& Ismaila, M. (2014). Empirical investigation of the impact of monetary policy on manufacturing sector performance in Nigeria (1986-2012). International Journal of Education and Research, 2 (1), 1-20.

Iyoha, M. I., \& Oriahki, D. E. (2002). Explaining African economic growth performance: The case of Nigeria. A Revised Interim Report on Nigerian Case Study for The African Economic Research Consortium, May.

Jhingan, M. L. (2008). Monetary economics (6th ed.). Delhi: Vrinda Publications Limited. 
John, E. I., \& Udoye, O. N. (2018). Effect of monetary policy on Nigerian economy. Journal of Humanities, Management and Social Sciences, 1 (1), 190-217

Levine, R., \& Renelt, D. (1992). A sensitivity analysis of cross-country growth regressions. American Economic Review, 82, 942-963.

Lucas, R. J. (1972). Expectations and the neutrality of money. Journal of Economic Theory, 4 (2), 103-144.

Nwoko, P. N., Ihemeje, J. C., \& Anumadu, E. (2016). Impact of monetary policy on economic growth in Nigeria. African Reasearch Review: An International Multidisciplinary Journal, Ethiopia, 10 (3), 23-34.

Obadan, M. I., \& Ayodele, A. S. (1998). Commercialization and privatization policy in Nigeria. Centre for Economic Management and Administrative Research, University of IbadanNigeria.

Ogbonna, B. M., \& Uma, K. E. (2017). Monetary policy, inflation and economic growth in Nigeria. International Journal of Research in Management, Economics and Commerce, 7 (10), 126-134.

Ogbulu, O. M., \& Torbira, L. L. (2012). Budgetary operations and economic growth: The Nigerain perspective. British Journal of arts and Social Sciences, 4 (2), 180-194.

Ogunmuyiwa, M. S., \& Ekone, A. F. (2010). Money supply-economic growth nexus in Nigeria. Journal of Social Sciences, 22 (3), 199-204.

Oluseyi, A. S., Olasehinde, T. J., \& Eweke, G. O. (2017). The impact of money supply on Nigeria economy: A comparison of mixed data sampling (MIDAS) and ARDL approach. EuroEconomica, 2 (36), 123-134.

Omolade, A., Ashamu, S. O., \& Morakinyo, A. (2013). Monetary policy and Nigeria's economic growth. IOSR Journal of Economics and Finance (IOSR-JEF), 1, (3), 123-146.

Pesaran, M. H., Shin, Y., \& Smith, R. J. (2001). Bounds testing approaches to the analysis of level relationships. Journal of Applied Econometrics, 16, 289-326.

Petrakos, G., Arvanitidis, P., \& Pavleas, S. (2009). Determinants of economic growth: The view of the experts. Dynamic Regions in a Knowledge Driven Global Economy Lessons and Policy Implications for the EU. Discussion Paper Series, 15 (1), 1 - 22.

Ristanović, V. (2010). Macroeconomic determinants of economic growth and world economic financial crisis. Facta Universitatis Series. Economics and Organization, 7 (1), 17-33

Solow, R. (1956). A contribution to the theory of economic growth. Quarterly Journal of Economics, 70 (1), 65-94. http://dx.doi.org/10.2307/1884513

Swan, T. W. (1956). Economic growth and capital accumulation. Economic Record, 32, 334 61. http://dx.doi.org/10.2307/1884513

Todaro, M. P., \& Smith, S. C. (2009). Economic development. Harlow, England: AddisonWesley.

Tule, M. K., Ogundele, O. S., \& Apinran, M. O. (2018). Efficacy of monetary policy instruments on economic growth: Evidence from Nigeria. Asian Economic and Financial Review, 8 (10), 1239-1256.

Twinoburyo, E. N., \& Odhiambo, N. M. (2018). Monetary policy and economic growth: A review of international literature. Journal of Central Banking Theory and Practice, 2 , 133-137.

Ufoeze, L. O., Odimgbe, S. O., Ezeabalisi, V. N., \& Alajekwu, U.B. (2018). Effect of monetary policy on economic growth in Nigeria: An empirical investigation. Annals of Spiru Haret University, Economic Series, Universitatea Spiru Haret, 9 (1), 123-140. 